\title{
MEASUREMENTS OF THE CHARACTERISTICS OF THE SUSPENDED LOAD AND MICRO-ORGANISMS IN THE SAVA RIVER RESERVOIR, SLOVENIA
}

\author{
B. DOLINAR \& H. VRECL KOJC \\ Department of Geotechnical Engineering, Faculty of Civil Engineering, University of Maribor, Slovenia.
}

\begin{abstract}
This article presents the results of investigations regarding suspended load and micro-organisms in the reservoir of the Boštanj hydroelectric power plant on the Sava River in Slovenia. The purpose of the described study was to estimate the quantity of suspended load in the water, its chemical and mineralogical composition, and to investigate the micro-biological and organic parts in water in order to provide a baseline for further, more detailed studies relating to the impact of reservoir construction. The results of the quantitative analyses of the suspended load in the water showed the exponential correlation between the concentration of the suspended load and the water discharge.
\end{abstract}

Keywords: reservoir, sedimentation, sediment transport, suspended load.

\section{INTRODUCTION}

All rivers contain sediments: a river, in effect, can be considered a body of flowing sediments as much as it can be considered a body of flowing water. And when a river is stilled behind a dam, these sediments it contains tend to sink to the bottom of the reservoir. The proportion of a river's total sediment load captured in a reservoir approaches 100 per cent for many projects, especially those with large reservoirs. As the sediments accumulate in the reservoir, the dam gradually loses its ability to store water for the purposes for which it was built. In fact every reservoir loses storage to sedimentation, although the rate at which this happens varies widely.

Despite more than seven decades of research, sedimentation is still probably the most serious technical problem faced by the dam industry. Haque [1] estimated that around 50 cubic kilometres of sediment - nearly 1 per cent of the global reservoir storage capacity - is trapped behind the world's dams every year. The rate of this reservoir sedimentation depends mainly on the size of the reservoir relative to the amount of sediment flowing into it: a small reservoir on an extremely muddy river will rapidly lose capacity; a large reservoir on a very clear river may take centuries to lose an appreciable amount of storage. In 1996 McCully [2] reported that large reservoirs in the US lose storage capacity at an average rate of around 0.2 per cent per year, with regional variations ranging from 0.5 per cent per year in the Pacific states to just 0.1 per cent in reservoirs in the northeast. Major reservoirs in China lose capacity at an annual rate of 2.3 per cent.

Sediment flows vary widely, both annually and seasonally, over time - far more than water flows and so calculating an annual average needs a long run of data. The amount of sediment carried into a reservoir is at its highest during floods: in the US, for example, commonly half of a river's annual sediment load may be transported during only 5-10 days of flow. During and after a particularly violent storm a river may carry as much sediment as it would in several 'normal' years. Global warming, which is predicted to cause more intense storms, will likely increase both the unpredictability and rate of reservoir sedimentation. The actual process of sediment deposition is unique to every reservoir and is impossible to predict accurately. In general, the coarser, heavier sediments, the gravel and sand, tend to settle out at the upper end of the reservoir, forming a 'backwater' delta, which gradually advances toward the dam. The lighter sediments, the silt and clay, tend to be deposited nearer the dam [2]. 
The next important effect on the sedimentation process is the time-dependent activity of microorganisms. For example, a field experiment was undertaken in 1991 at Lake Barre, in the Louisiana coastal zone in the USA, with the primary goal of acquiring a better understanding of time-mean flow and sediment transport [3]. The former was attributed to current ripples, while the latter appeared to be related to the activity of benthic organisms. The large positive, vertical sediment gradient that appeared during the first cold front was attributed to advection of the sediment from an area of rapid degradation upstream. Sediment-transport calculations reveal fluxes of the sediment from the marsh into the study area during cold-front passages, the largest magnitudes being associated with the earliest cold fronts. The results suggest that the flux magnitude generally decreased with each succeeding cold front.

To make a meaningful economic forecast for a planned reservoir, it is necessary to be able to predict its sedimentation rate with reasonable accuracy. However, it is extremely difficult to estimate how much sediment will be trapped by a reservoir. Investigations in the past showed that there are a lot of factors that impact on the sedimentation process. This paper presents a non-standard approach to suspended-load investigations that considers various relevant impacts. The investigated reservoir of the hydroelectric power plant is located on the Sava River [4], which is the longest river in Slovenia and passes $2207 \mathrm{~km}$ across geologically, geographically and climatologically agitated areas. The investigated reservoir of the Boštanj hydroelectric power plant on the Sava River in Slovenia is $5 \mathrm{~km}$ long and, on average, $150 \mathrm{~m}$ wide.

\section{CONSIDERATION OF RELAVANT IMPACTS}

\subsection{Suspended-load investigation}

The suspended-load investigations were divided into three stages: field investigations, laboratory investigations and a numerical evaluation of the results.

The field investigations were focused on the two most important impacts. As the first relevant impact was assumed to be the river discharge, the sampling procedure was performed continuously with the intention of collecting data about the suspended load at low and high discharges. The second relevant impact was the locations from which the samples of water were taken, because it was assumed that the quantity and composition of the suspended load depends on the location. The areas of the water sampling were the intake and outflow from the reservoir. At the same time, the flow rate of the river and its temperature were examined during the sampling.

The laboratory investigations firstly focussed on the procedure for receiving the solid particles from the water with the help of sedimentation and water evaporation. With such an approach, sufficient quantities of suspended material for further investigations were ensured. The relevant impacts at this stage are twofold, i.e. research on the quantity of suspended material, with a particle size analysis; and research on the quality, with mineralogical and chemical analyses of the suspended material.

The final result of the chosen approach for the suspended-load investigations was achieved with a numerical evaluation of the results. Considering all of the aforementioned impacts, the different relationships can be re-established and presented in diagrams.

\subsection{Micro-organisms}

The time-dependent activity of micro-organisms [3] is the next important effect of the sedimentation process. For this reason the micro-organisms and the small organic parts in the open river water were also investigated. 


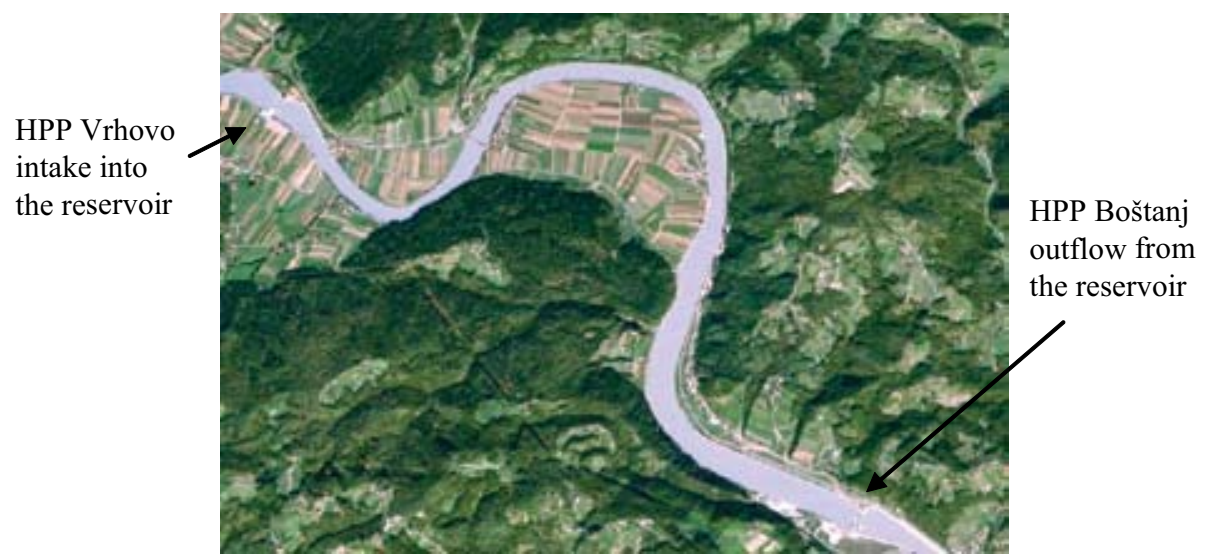

Figure 1: Water-storage reservoir of the HPP Boštanj on the Sava River.

Micro-organisms are very small, living features that are usually observed with a microscope when we wish to analyse their morphology and physiology. However, detection tests are used to investigate their presence and the extent of their abundance. With some of the ID methods their systematic and taxonomy, and with toxicology tests the type of toxins they usually produce, are estimated. Many groups of micro-organisms present in every kind of habitat are very important in ecosystems, because of the large range of activities; for example, decomposition, photosynthesis and so on. It is also the case that there are a lot of pathogenic species because of the destructive human impact on nature and the environment. These facts are presumed to also have a relevant impact on the sedimentation process, and therefore it is important to investigate the species and the quantity of micro-organisms present in the observed media.

\section{SUSPENDED-LOAD INVESTIGATIONS}

\subsection{Field investigations}

The treated water-storage reservoir of a useful volume of $1,000,000 \mathrm{~m}^{3}$ is shown in Fig. 1. The water samples, from which the suspended material was removed, were taken at the intake of the water into the reservoir and at its outflow. For reasons of data comparability, the water was always taken at the same place - in front of the power station located on the right side of the river bank at a depth of $1 \mathrm{~m}$.

A total of 24 samples were collected, and each contained at least 401 of water. At the site of the sample collection, the discharge of the Sava River and its temperature were examined during the sampling (Table 1).

\subsection{Laboratory investigations}

The suspended material and the water were separated with the help of the sedimentation of the particles by centrifuging and water evaporation (Table 1). The chosen approach required a lot of time, but it enabled us to determine the quantity of suspended material very precisely and to collect enough material for further investigations. 
Table 1: Sampling time, temperature of the water $(\mathrm{T})$, discharge $(\mathrm{Q})$, concentration of the suspended load (c).

\begin{tabular}{lcrrr}
\hline Sample & Date & $\mathrm{T}\left({ }^{\circ} \mathrm{C}\right)$ & $\mathrm{Q}\left(\mathrm{m}^{3} / \mathrm{s}\right)$ & $\mathrm{c}\left(\mathrm{g} / \mathrm{m}^{3}\right)$ \\
\hline 1 Intake & 01.09 .2006 & 13.3 & 175 & 6.8 \\
1 Outflow & & 16.6 & 152 & 1.1 \\
2 Intake & 20.09 .2006 & 13.0 & 252 & 12.7 \\
2 Outflow & & 13.0 & 252 & 8.6 \\
3 Intake & 26.10 .2006 & 12.0 & 248 & 19.6 \\
3 Outflow & & 12.5 & 264 & 10.0 \\
4 Intake & 15.11 .2006 & 9.5 & 65 & 1.7 \\
4 Outflow & & 6.5 & 210 & 0.8 \\
5 Intake & 23.11 .2006 & 10.0 & 180 & 18.3 \\
5 Outflow & & 10.0 & 134 & 18.3 \\
6 Intake & 10.0 & 130 & 5.8 \\
6 Outflow & 10.0 & 407 & 8.3 \\
7 Intake & & 9.5 & 383 & 47.5 \\
7 Outflow & 11.12 .2006 & 9.5 & 478 & 75.0 \\
8 Intake & & 7.0 & 525 & 40.8 \\
8 Outflow & 24.01 .2007 & 9.0 & 340 & 15.8 \\
9 Intake & & 10.0 & 316 & 11.3 \\
9 Outflow & 09.03 .2007 & 10.0 & 100 & 6.6 \\
10 Intake & & 15.0 & 74 & 0.8 \\
10 Outflow & 24.04 .2007 & 15.0 & 63 & 1.7 \\
11 Intake & & 17.0 & 79 & 5.8 \\
11 Outflow & 21.05 .2007 & 17.0 & 62 & 5.2 \\
12 Intake & & 19.5 & & 3.7 \\
12 Outflow & 05.06 .2007 & 19.5 & & \\
\hline
\end{tabular}

\subsubsection{Particle size analyses}

The particle size analyses of the solids were carried out by the Geological Survey of Slovenia using an Analysette 22"/Nano Tec laser particle sizer made by FRITSCH GmbH - Manufacturers of Laboratory Instruments, Germany. Analytical instruments based on laser diffraction for the determination of the particle size distribution use the physical principle of the scattering of electromagnetic waves. The design consists of a laser beam directed through a measuring cell to a detector. A dispersion module transports the particles to the measuring cell and through the laser beam. The light scattered in proportion to the particle size is projected by a lens onto a detector. The particle size distribution can be calculated from the distribution of scattered light with the help of complex mathematics.

The grain size analyses were performed on 16 samples from the intake and outflow areas of the water from the reservoir. The samples from both sites were collected simultaneously, and therefore the discharge of the water was similar. In this way it is possible to compare the particle sizes in the suspension with respect to the collection site. The results of the analyses show that the suspended load mostly has the size of silt, and only 5-20 per cent of the grains belong to the clay fraction. Larger grains were found at the water-intake site, when an increased share of the clay fraction 


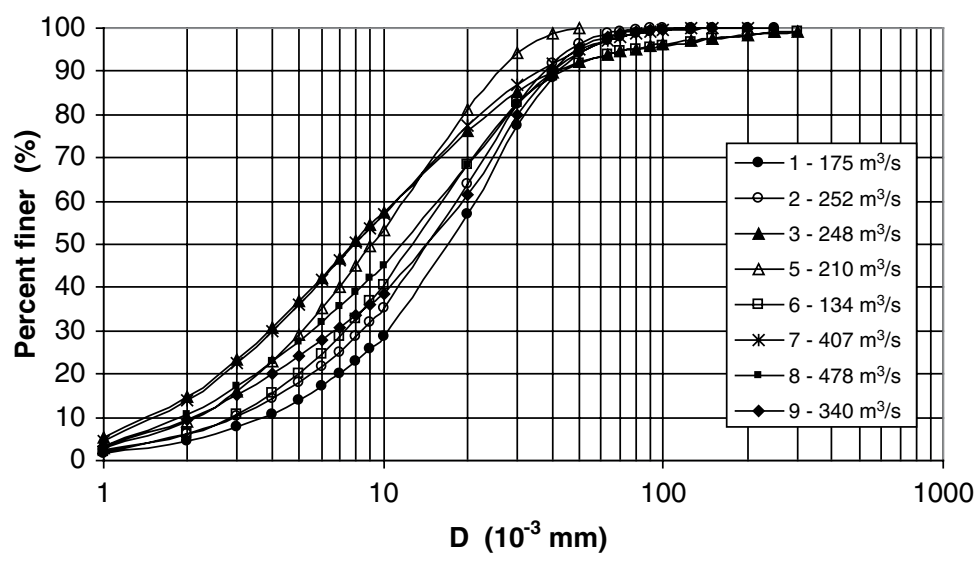

Figure 2: Grain size distribution of the suspended load at the water intake into the reservoir.

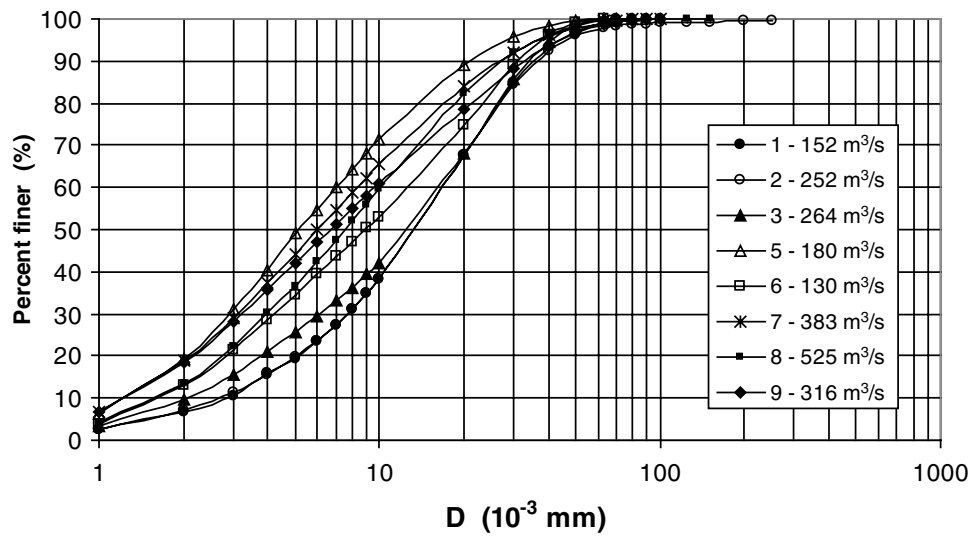

Figure 3: Grain size distribution of the suspended load at the outflow of the water from the reservoir.

was observed at the outflow. The results of the grain size analyses for the individual samples are presented in Figs 2 and 3 with the discharges at the times of the sample collection marked in the legend.

The difference in the size of the suspended load between the first and the final parts of the reservoir is presented in Fig. 4, where the grain size distribution is provided for the composed samples from individual sites.

The ratio between the concentration of the suspended material $\left(\mathrm{g} / \mathrm{m}^{3}\right)$ and the grain size at the water intake and outflow sites from the reservoir is presented in Fig. 5. It is evident that the quantity of larger grains $(10-100 \mu \mathrm{m})$ of solids in the water is smaller at the outflow from the reservoir than at the intake. 


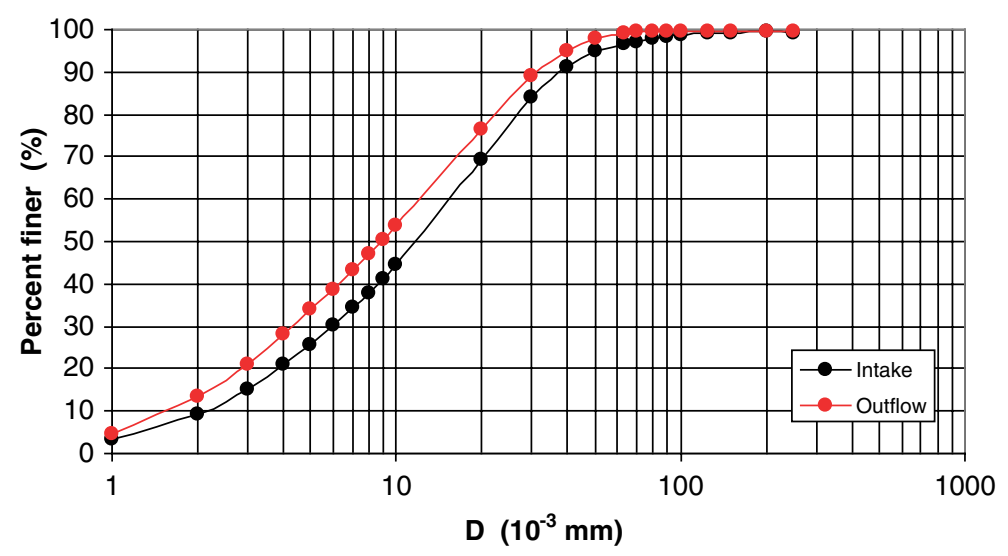

Figure 4: Comparison of the grain sizes of the composed samples of solids from the intake and the outflow areas of the water from the reservoir.

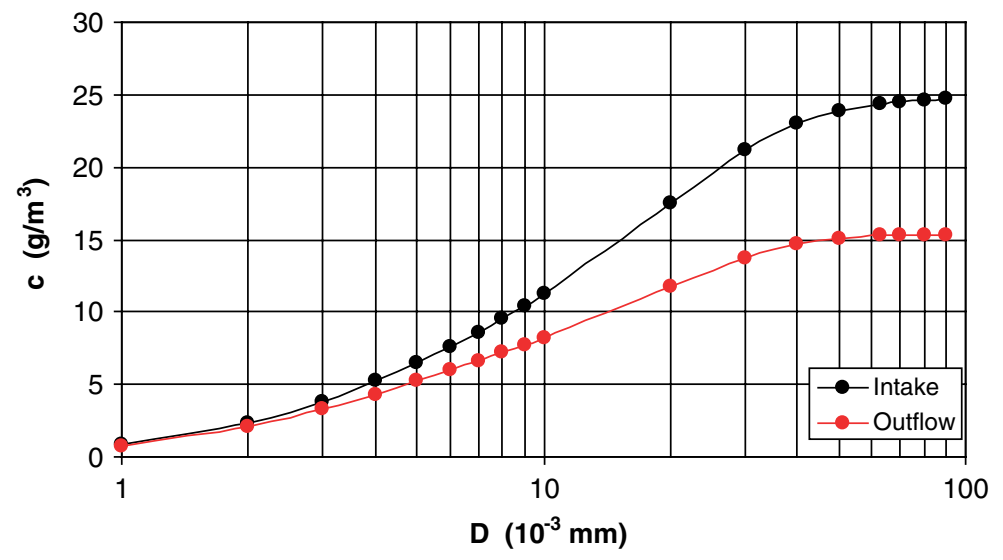

Figure 5: Relationship between the concentrations of the suspended load and the grain sizes of the composed samples from both collection sites.

\subsubsection{Chemical composition of the suspended material}

The results of the chemical analyses will be used to check and confirm the quantities of the individual minerals in the soils. The chemical composition of the soils was determined at the Acma Analytical Laboratories Ltd., Vancouver. The inductively coupled plasma emission spectrometry method was used to determine the main elements, both quantitatively and qualitatively, while inductively coupled plasma mass spectrometry was used to determine the trace elements. Carbon and sulphur were determined with a Leco analyser and the $\mathrm{FeO}$ by dichromate titration.

The chemical composition of the composed sample of the suspended material from the reservoir and the mineral composition of the composed samples from the water intake and outflow areas are presented in Table 2. 
Table 2: Mineral and chemical compositions of the suspended load.

\begin{tabular}{lccccc}
\hline Mineral composition (\%) & & & \multicolumn{2}{c}{ Chemical composition (\%) } \\
\cline { 5 - 6 } & Intake & Outflow & & $\mathrm{SiO}_{2}=37.76$ & $\mathrm{TiO}_{2}=0.54$ \\
\hline Muscovite/illite & 33 & 33 & & $\mathrm{Al}_{2} \mathrm{O}_{3}=13.43$ & $\mathrm{P}_{2} \mathrm{O}_{5}=0.32$ \\
Chlorite & 15 & 15 & & $\mathrm{Fe}_{2} \mathrm{O}_{3}=5.12$ & $\mathrm{MnO}^{2} 0.12$ \\
Quartz & 17 & 21 & & $\mathrm{MgO}^{2}=2.85$ & $\mathrm{Cr}_{2} \mathrm{O}_{3}=0.016$ \\
Plagioclase & 5 & 5 & & $\mathrm{CaO}=11.15$ & $\mathrm{TOT}^{2} \mathrm{C}=7.62$ \\
Calcite & 20 & 18 & & $\mathrm{Na}_{2} \mathrm{O}=0.57$ & $\mathrm{TOT} / \mathrm{S}=0.06$ \\
Dolomite & 10 & 8 & & $\mathrm{~K}_{2} \mathrm{O}=2.20$ & LOI $=25.6$ \\
\hline
\end{tabular}
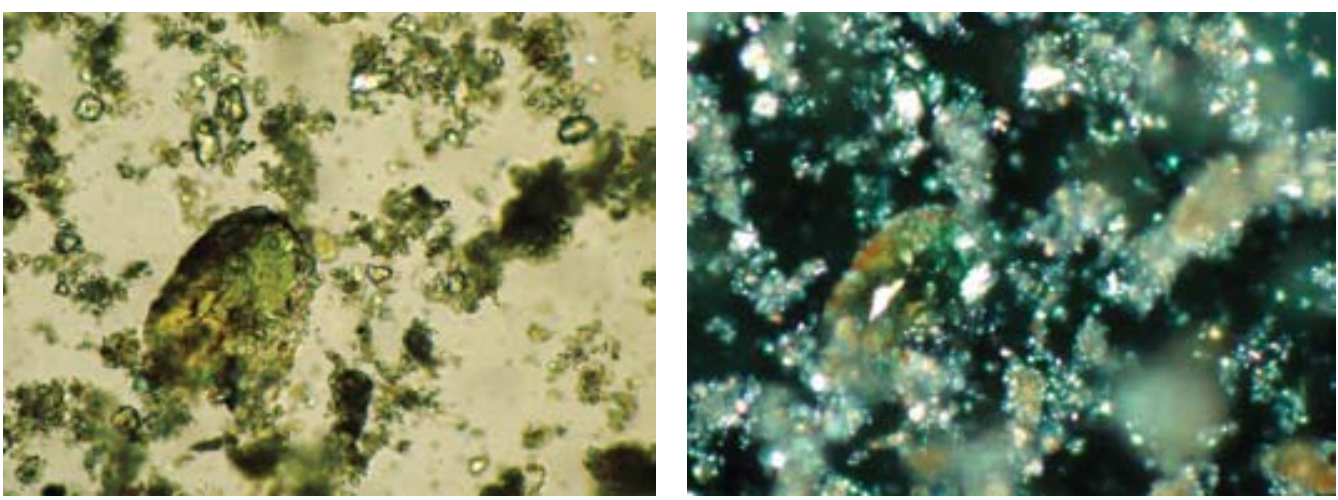

Figure 6: Suspended load at the intake of the water into the reservoir.

\subsubsection{Mineral composition of the suspended material}

The bulk and clay mineralogy of the soil samples were determined by the Geological Survey of Slovenia using X-ray diffraction techniques. The samples were scanned using a Philips PW 3710 $\mathrm{X}$-ray diffractometer with an 1820 goniometer, an automatic divergence slit and a curved-crystal graphite monochromator. This instrument was operated at $40 \mathrm{kV}$ and $30 \mathrm{~mA}$ using $\mathrm{CuK} \alpha$ radiation. The bulk mineralogy was determined on a whole-soil sample. The semi-quantitative mineralogical composition of the bulk soil samples was calculated using the methods of Shultz [5] and Biscaye [6].

A microscopic examination of the solid from the intake and the outflow of water from the reservoir (Figs 6 and 7) did not show any special difference in terms of the mineral composition. Only a larger quantity of organic detritus and clay particles and the absence of rare heavy minerals are evident among the suspended material at the outflow of water.

Green chlorite, transparent carbonate grains, black non-transparent matter and sub-microscopic particles of clay and carbonate minerals; II N (Fig. 5 left) and + N (Fig. 5 right), zoom: 190 X.

The larger grains belong to the black, non-transparent matter, the transparent carbonate grains, the rare silicate leaves, the quartz, the fine green chlorite and the sub-microscopic particles of clay minerals; II N (Fig. 7 left) and + N (Fig. 7 right), zoom: $170 \mathrm{X}$. 

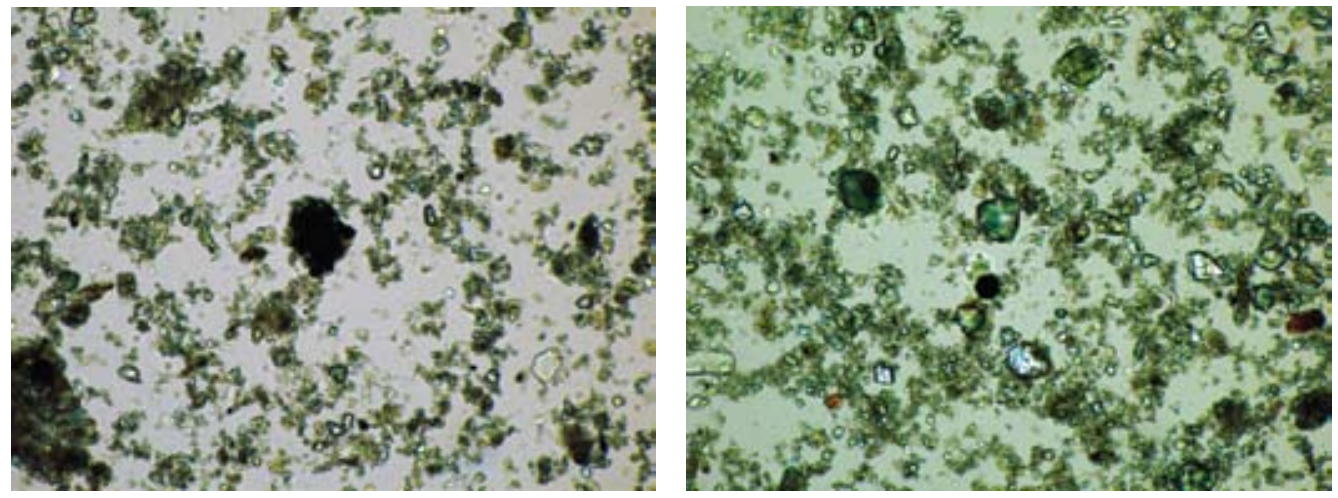

Figure 7: Suspended load at the outflow of the water from the reservoir.

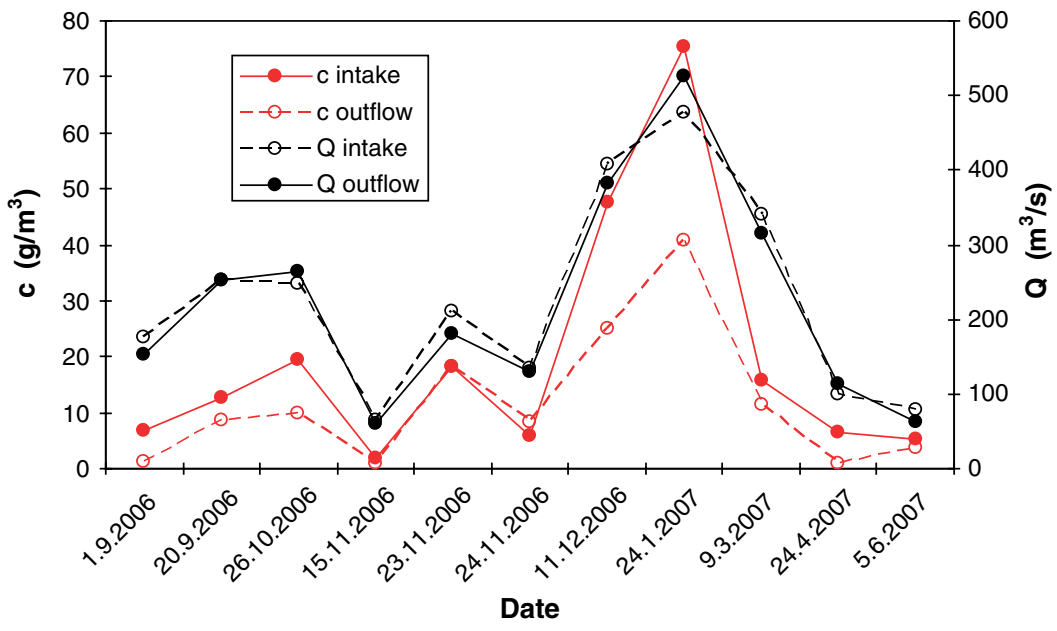

Figure 8: The concentration of the suspended load in relation to the discharge and the time periods of the sample collection.

The comparison of the mineral composition of the samples from both sites shows a smaller share of carbonate particles and larger share of quartz at the outflow of the water from the lake than at the intake (Table 2).

\subsection{Numerical evaluation of the results}

\subsubsection{Concentration of the suspended load}

The concentration of the suspended load in the watercourses depends on many factors from the environment, which is why a study of the dynamics of their transport and sedimentation is quite demanding [7]. However, at an individual measuring station we can see a correlation between the concentrations of the suspended material and the flow rates of the water [8].

The results of the measurements at selected sites of the reservoir showed that the share of suspended load increases with the increase of the discharge (Table 1). This ratio is shown in Fig. 8, 


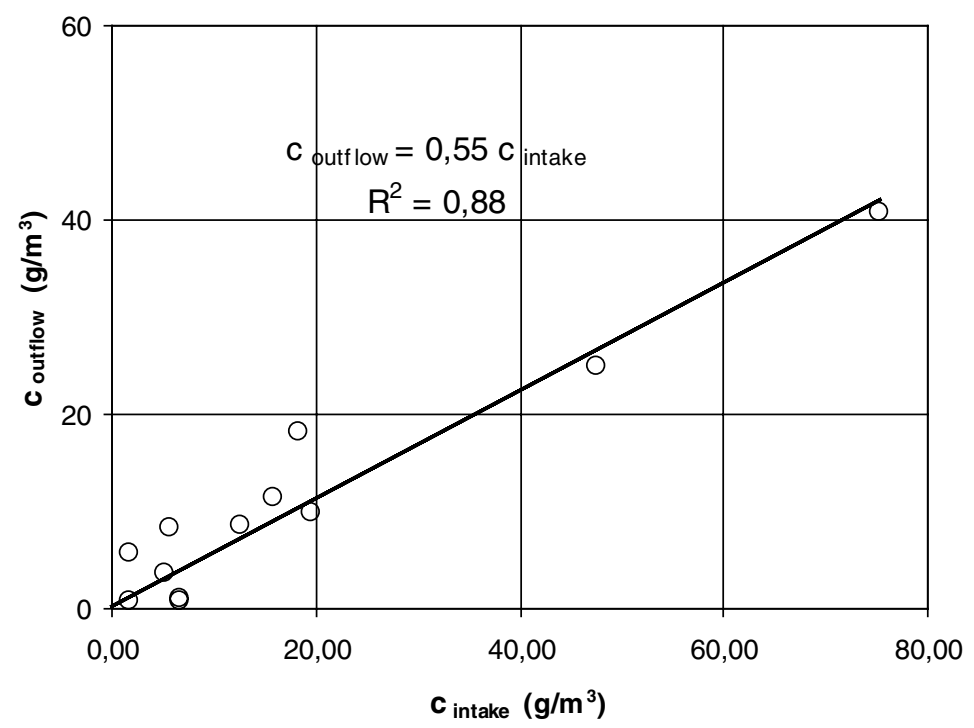

Figure 9: Ratio between the concentrations of the suspended load at the intake and at the outflow of the water from the reservoir.
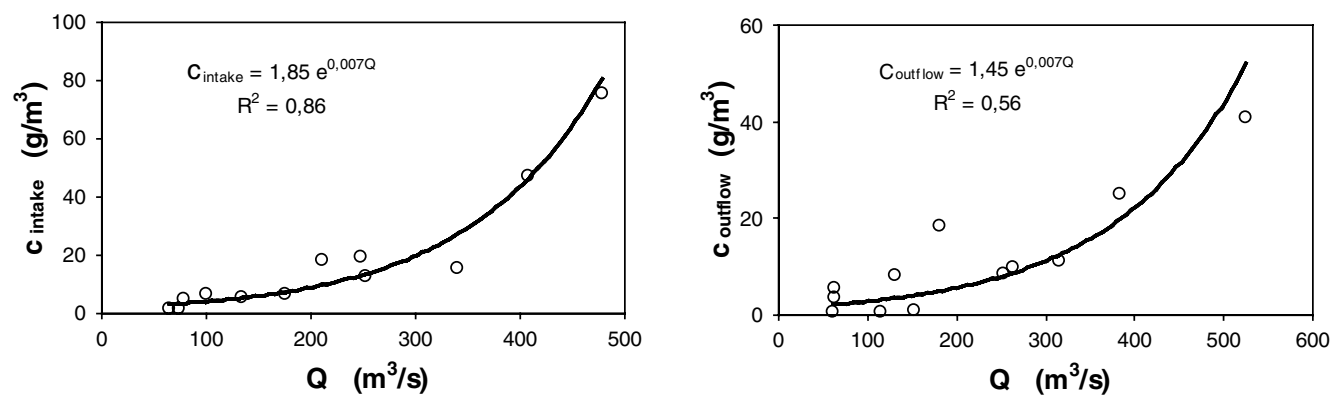

Figure 10: The concentration of the suspended load in relation to the discharge at the intake (fig. left) and outflow (fig. right) of the water from the reservoir.

in which both variables are presented separately for the samples from the intake and the outflow site of the water from the reservoir. Due to an almost simultaneous collection of the samples from both sites, the discharge was very similar; however, there is a difference in the quantity of the suspended material, which is much smaller at the water outflow.

A comparison of the concentrations of the suspended load from both collection sites showed that this ratio is approximately linear (Fig. 9). We can describe it using eqn (1).

$$
\mathrm{c}_{\text {outlow }}=0.55 \cdot \mathrm{c}_{\text {intake }}
$$

From the concentrations of the suspended load at the water intake and outflow, and the discharges (Fig. 10), it is clear that it is possible to describe these ratios with eqns (2) and (3). 


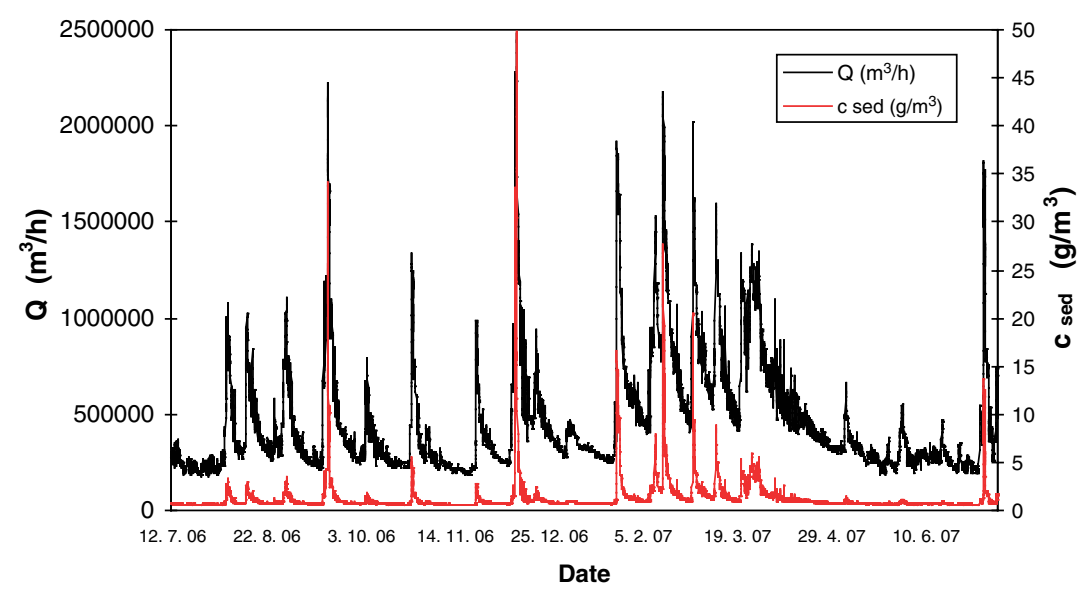

Figure 11: The discharge and the quantity of deposited material for the period of one year.

$$
\begin{gathered}
\mathrm{c}_{\text {intake }}=1.85 \cdot \mathrm{e}^{0.007 \mathrm{Q}} \quad\left(\mathrm{g} / \mathrm{m}^{3}\right) \\
\mathrm{c}_{\text {outflow }}=1.45 \cdot \mathrm{e}^{0.007 \mathrm{Q}} \quad\left(\mathrm{g} / \mathrm{m}^{3}\right)
\end{gathered}
$$

\subsubsection{Estimation of the quantity of material}

The studies of the concentrations of the suspended load at both collection sites showed that there is less suspended load at the outflow of the water from the reservoir than at the intake. The difference is represented by the share of grains that sedimented on the bottom of the reservoir. By considering eqns (2) and (3) the quantity of these sediments $\left(\mathrm{c}_{\text {sed }}\right)$ can be expressed in relation to the discharge of water approximately with eqn (4).

$$
c_{\text {sed }}=c_{\text {intake }}-c_{\text {outllow }}=1.85 \cdot \mathrm{e}^{0.007 \mathrm{Q}}-1.45 \cdot \mathrm{e}^{0.007 \mathrm{Q}}=0.4 \cdot \mathrm{e}^{0.007 \mathrm{Q}}
$$

An estimation of the quantity of deposited material in the reservoir was prepared on the basis of the actual hourly discharges [9] for the period between 12 July 2006 and 12 July 2007 (Fig. 11).

\section{MICRO-ORGANISM INVESTIGATIONS}

\subsection{Sampling procedure}

The objective here was to investigate the presence of the micro-organisms living in open river water. The samples were tested for some viruses, bacteria, fungi, algae, protozoa and other animals. We also tried to detect the presence of small organic parts in the open river water. Two main measurements were performed: the first one on 5 February 2007, during the winter period, and the second one on 18 May 2007, in the spring time. Samples were taken from the river water at three locations, e.g. at the inflow of the water to the reservoir, at the middle of it and at the outflow.

At each location, environmental parameters such as the $\mathrm{pH}$ of the water, the temperature of the water and the temperature of the air were measured. The equipment used in the field was sterile, 


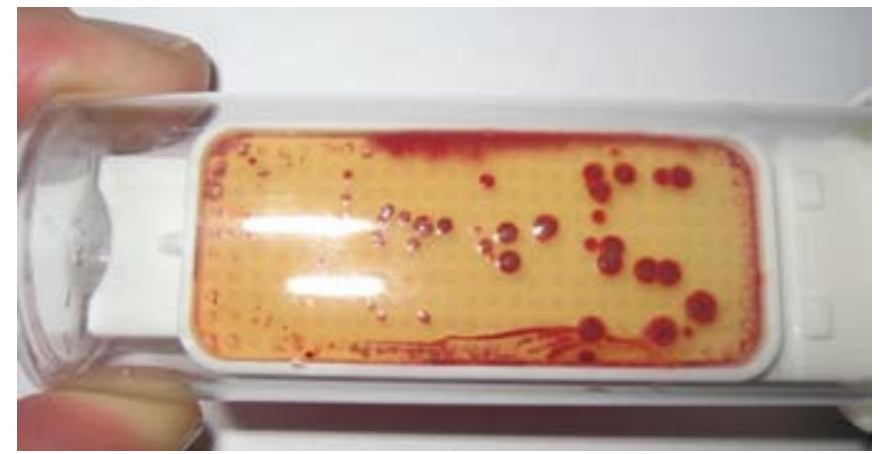

Figure 12: Growth of bacteria colonies on the prepared plate media.

auto-cleavable plastic buds with a cap for the liquid samples, a sterile pipette for taking liquid samples, a $\mathrm{pH}$ meter, a digital thermometer with sound, a refrigeration bag, alcohol pens and sample lists.

\subsection{Laboratory investigation}

The laboratory equipment used during the investigation was a microscope, object glass slides for counting the cells and pieces during the microscopy, a millilitre pipette, an incubator, fast detecting tests for the viruses, prepared plate media for bacteria and fungi, an autoclave and sample lists (Fig. 12).

In this investigation the time was very important; therefore, the observations and tests were started as soon as possible. For each parallel of every sample, a fast detection test on the Rota and adenoma viruses and also on the influenza viruses was performed initially. Then, the water sample was inoculated on prepared plate media. These media were then incubated, at $37^{\circ} \mathrm{C}$ for $24 \mathrm{~h}$ for the bacteria and at $30^{\circ} \mathrm{C}$ for $48 \mathrm{~h}$ or more for the fungi. While waiting for these results the samples were investigated with microscopy. From each sample pipette, three parallels of $0.1 \mathrm{ml}$ of water were prepared and then microscopy was used to test for the presence of algae, protozoa, other animals and small organic parts.

\subsection{Evaluation of the results}

The results are presented in terms of the number of cells per millilitre. From this we were able to estimate the level of contamination in the water. Three classes are presented, with the numbers $1,3$ and 5 ( $1=$ low contamination, $3=$ intermediate contamination, $5=$ high contamination $)$. These levels of contamination are reflected in the total count of bacteria: $1 \mathrm{st}$ class $=50-1000$ cells $/ \mathrm{ml}$, $3 \mathrm{rd}$ class $=10,000-100,000 \mathrm{cells} / \mathrm{ml}$ and 5 th class $=1,000,000-10,000,000 \mathrm{cells} / \mathrm{ml}$.

In the winter time the $\mathrm{pH}$ levels were, on average, 8.74 , and were almost constant for the different measuring locations. In the spring time the values were slightly lower than either the winter or the summer time.

There were no viruses in the water samples, the emphasis being on the more pathogenic species that can cause some diseases and can be transported in rivers by faecal or waste waters, for example, the Rota and adenoma viruses, which cause human diarrhoea, and influenza viruses. The concentration 
Table 3: Concentration of the microscopic algae.

\begin{tabular}{lcc}
\hline Location & Algae/ml (winter) & Algae/ml (spring) \\
\hline Inflow & 20 & 20 \\
Middle of reservoir & $0-10$ & 20 \\
Outflow & $10-20$ & 30 \\
\hline
\end{tabular}

Table 4: Concentration of the organic parts.

\begin{tabular}{lcc}
\hline Location & Algae/ml (winter) & Algae/ml (spring) \\
\hline Inflow & 630 & 180 \\
Middle of reservoir & 150 & 130 \\
Outflow & 60 & 540 \\
\hline
\end{tabular}

of bacteria was more or less constant at all the locations. These concentrations were around 50 cells $/ \mathrm{ml}$. Only at the last location was the concentration decreased slightly. In the spring time the concentration was double, with 100 cells/ml. Microscopic fungi were, in practical terms, not present in most of the samples. However, in the winter time, mould was present at two locations. The concentration of microscopic algae is presented in Table 3, where it is clear that algae, like with the bacteria, are twice as numerous in the spring time. The amount of protozoa in the winter and spring time is almost the same, the number being about 10-20 organisms $/ \mathrm{ml}$.

The number of organic parts in the water of the Sava River varied the most for the two periods of time. Table 4 presents the results for the organic parts for both seasons. The lowest concentration of organic parts, for both seasons, was at location 2 in the middle of the reservoir. The water of the Sava River was always in the 1st class of contamination, i.e. a low level of contamination [10].

\section{CONCLUSIONS}

This article presents the results of suspended-load and micro-organisms investigations in the reservoir of the Boštanj hydroelectric power plant on the Sava River in Slovenia. The chosen, nonstandard approach of collecting and separating the suspended material from the water enabled us to determine the quantity of material very precisely and also to define its particle size and chemical and mineralogical composition.

The results of the studies showed that the concentration of the suspended material changes in relation to the flow rate of the water. This ratio can be described with an exponential function. It was determined that the concentration of the suspended load, for the same flow rate of water, is larger at the outflow than at the intake to the reservoir. The difference is represented by the material that was sedimented in the reservoir due to the decreased speed of the water as a result of the river's impoundment. Based on the ratio between the concentration of the suspended load and the size of the grains at the intake and the outflow of the water, it can be concluded that, in particular, the particles with a size between 10 and $100 \mu \mathrm{m}$ were sinking.

A comparison of the composition of the samples from both collection sites showed that at the outflow site of the water from the reservoir there is a somewhat smaller share of carbonate grains and heavy minerals than at the intake site, and a higher content of organic detritus and clay particles can also be observed. In the composition of the suspended load, carbonates, muscovite/illite and quartz 
dominate; however, chlorite was also found, as well as small quantities of plagioclase and organic detritus. With regard to the size of the particles, the examined samples are classified as silt.

Concerning the micro-biological investigation, the samples from the Sava River were always in the 1 st class of contamination, which means a low contamination, and therefore further estimations relating to the microbiological effects on the sedimentation process were not appropriate.

The importance of this study for the sustainable development and planning of the river reservoir is the suspended-sediment monitoring, its chemical and mineralogical composition and investigation of the micro-biological and organic parts in order to provide a baseline for future reservoir cleaning.

\section{REFERENCES}

[1] Haque, M.I. \& Mahmood, K., Sediment convection-diffusion and bedform length. Journal of Hydraulic Engineering, ASCE, 113(11), pp. 1381-1401, 1987. doi:10.1061/(ASCE)07339429(1987)113:11(1381)

[2] McCully, P., The Ecology and Politics of Large Dams, Zed Books: London, 1996.

[3] Adams, C.E., Xu, L., Walker, N.D. \& Murray, S.P., Flow and sediment transport in a shallow bar-built estuary, northern Gulf of Mexico. Journal of Coastal Research, 13(1), pp. 164-180, 1997.

[4] Dolinar, B., Vrecl-Kojc, H. \& Trauner, L., Analysis of concentration and sedimentation of suspended load in the reservoirs. Acta Geotechnica Slovenica, 5(2), pp. 30-39, 2008.

[5] Schultz, L.G., Quantitative interpretation of mineralogical composition from X-ray and chemical data for the Pierre Shale. US Geological Survey, Professional Papers 391 c, 1964.

[6] Biscaye, P.E., Mineralogy and sedimentation of recent deep-sea clay in the Atlantic ocean and adjacent sea and oceans. Geol. Soc. AM. Bull., 76, pp. 803-831, 1965. doi:10.1130/0016-7606(1965)76[803:MASORD]2.0.CO;2

[7] Rusjan, S. \& Mikoš, M., Suspended load transport dynamics in river basins. Acta hydrotechnica, 40, pp. 1-20, 2006.

[8] Ulaga, F., The content and transport of suspended material in the Slovenian rivers. Environmental Agency of the Republic of Slovenia, 2005.

[9] Vrecl-Kojc, H., Dolinar, B., Klasinc, R. \& Trauner, L., Analyses of the suspended-load sedimentation process and its dynamics in reservoirs with high daily oscillations. Acta Geotechnica Slovenica, 5(2), pp. 41-49, 2008.

[10] Trauner, L., Škrabl, S., Žlender, B., Dolinar, B., Macuh, B., Vrecl-Kojc, H., Šketelj, E., Petrešin, E., Jecl, R., Nekrep, M., Lobnik, A., Poberžnik, M., Turel, M., Zlatolas, D., Greifoner, R., Bauman, M. \& Senica, H., Development of the Technology to Remove Sediments and Debris Before the Accumulation Dams: Development and Investment Project. The final report. Faculty of Civil Engineering, Maribor, 2007. 